medRxiv preprint doi: https://doi.org/10.1101/2021.12.21.21268077; this version posted January 14,2022 . The copyright holder for this preprint (which was not certified by peer review) is the author/funder, who has granted medRxiv a license to display the preprint in perpetuity.

It is made available under a CC-BY 4.0 International license .

\title{
Quantitative detection of SARS-CoV-2 Omicron variant in wastewater through allele-specific RT-qPCR
}

Authors: Wei Lin Lee (1,2), Xiaoqiong Gu (1,2), Federica Armas (1,2), Fuqing Wu $(4,5)$, Franciscus Chandra (1,2), Hongjie Chen (1,2), Amy Xiao (4,5), Mats Leifels (3), Feng Jun Desmond Chua (3), Germaine WC Kwok (3), Joey YR Tay (1,2), Claire YJ Lim (1,2), Janelle Thompson $(2,3,6)^{\star}$, Eric J Alm $(1,2,4,5,7)^{\star}$

\section{Author Affiliations:}

1: Antimicrobial Resistance Interdisciplinary Research Group, Singapore-MIT Alliance for Research and Technology, Singapore

2: Campus for Research Excellence and Technological Enterprise (CREATE), Singapore

3: Singapore Centre for Environmental Life Sciences Engineering, Nanyang Technological University, Singapore

4: Center for Microbiome Informatics and Therapeutics, Massachusetts Institute of Technology

5: Department of Biological Engineering, Massachusetts Institute of Technology

6: Asian School of the Environment, Nanyang Technological University, Singapore

7: Broad Institute of MIT and Harvard, Cambridge, MA, USA

Key Words: SARS-CoV-2; COVID-19; Variant; RT-qPCR; Wastewater; surveillance; Omicron

Running title: Quantitative SARS-CoV-2 Omicron variant tracking in wastewater

* Correspondence to JT at janelle.thompson@ntu.edu.sg and EJA at ejalm@mit.edu 
medRxiv preprint doi: https://doi.org/10.1101/2021.12.21.21268077; this version posted January 14,2022 . The copyright holder for this
preprint (which was not certified by peer review) is the author/funder, who has granted medRxiv a license to display the preprint in perpetuity.

It is made available under a CC-BY 4.0 International license.

\section{ABSTRACT}

On November 26, 2021, the B.1.1.529 COVID-19 variant was named as the Omicron variant of concern. Reports of higher transmissibility and potential immune evasion triggered flight bans and heightened health control measures across the world to stem its distribution. Wastewater-based surveillance has demonstrated to be a useful complement for community-based tracking of SARS-CoV-2 variants. Using design principles of our previous assays that detect SARS-CoV-2 variants (Alpha and Delta), here we report two allele-specific RT-qPCR assays that can quantitatively detect the Omicron variant in wastewater and their validation against full length synthetic Omicron RNA. The first simultaneously targets mutations Q493R, G496S and Q498R, and the other targets the deletion at H69-V70 of the spike protein. This method is open-sourced and can be implemented using commercially available RT-qPCR protocols, and would be an important tool for tracking the spread and introduction of the Omicron variant in communities for informed public health responses.

\section{INTRODUCTION}

The COVID-19 disease was first detected late December 2019 and rapidly spread globally, leading to the WHO declaring it a global pandemic by March 2020 (WHO, 2020). The etiological cause of this disease is the single-stranded RNA virus SARS-CoV-2 of the genus Betacoronavirus which also contains other human respiratory pathogens such as SARS-CoV and MERS-CoV (Pal et al., 2020). SARS-CoV-2 infection in the respiratory and gastrointestinal tract is mediated by the binding between viral spike protein (S) and human angiotensin-converting enzyme 2 (ACE-2) receptor (Zhou et al., 2020). Over the course of the pandemic, multiple SARS-CoV-2 variants emerged due to genetic mutation of the viral genome. While many variants contain inconsequential mutations, some obtained mutations that confer higher fitness through increased transmissibility and the ability to elude medical countermeasures such as vaccines (Harvey et al., 2021). These variants are deemed by the WHO as variants of concerns (VOCs) due to their increased risk (CDC, 2021). To date, WHO has classified five variants as VOCs. These include Alpha (B.1.1.7), Beta (B.1.351), Gamma (P.1) and the Delta (B.1.617.2) variant, which emerged from India in October 2020 and 
medRxiv preprint doi: https://doi.org/10.1101/2021.12.21.21268077; this version posted January 14,2022 . The copyright holder for this preprint (which was not certified by peer review) is the author/funder, who has granted medRxiv a license to display the preprint in perpetuity.

It is made available under a CC-BY 4.0 International license .

quickly became the predominant strain by mid-2021 (WHO, 2021a). The fifth VOC, Omicron (B.1.1.529) and descendent lineages were reported in multiple countries in November 2021. The Omicron variant draws attention due to its high number of mutations, with 26-32 of them in the spike protein (WHO, 2021b). At the time of writing, the Omicron variant only makes up $10 \%$ of all COVID-19 cases but their rapid expansion in the South African region and global distribution amidst early reports of higher transmissibility and immune escape compared to the Delta variant has raised alarm for researchers and public health officials alike (Pulliam et al., 2021).

In light of the emergence of VOCs, surveillance efforts tracking their introduction and spread in both naive and vaccinated populations become important to fight the pandemic. Current widely-used method for variant surveillance involves sequencing of clinical samples. However, the accessibility of genomic sequencing is limited and unsustainable due to the high capital and operational costs and the specialised infrastructure requirements associated (Gwinn et al., 2019). Furthermore, a significant fraction of confirmed cases needs to be sequenced to generate a meaningful dataset. A complementary method of surveillance that has been drawing a lot of attention during this pandemic is wastewater-based surveillance (WBS). WBS promises a low-cost, real-time, and unbiased snapshot of entire populations within its catchment range (Polo et al., 2020; Thompson et al., 2020). It has been shown to be effective at determining SARS-CoV-2 circulation trends during this COVID-19 pandemic across different countries (Medema et al., 2020; Randazzo et al., 2020; Wu et al., 2021). Further, WBS has been used to track the introduction and spread of SARS-CoV-2 strains. Most of the efforts for variant tracking in wastewater rely on enriching and sequencing the environmental SARS-CoV-2 genome (Crits-Christoph et al., 2021; Fontenele et al., 2021; Napit et al., 2021). However, poor sensitivity towards low-frequency variants and the lack of quantitative modelling of the data generated limits widespread application (Van Poelvoorde et al., 2021). RT-qPCR-based methods targeting variant-specific mutants of the SARS-CoV-2 genome have been demonstrated for variant identification in clinical samples (Wang et al., 2021) and we and others have recently adapted and validated use of such assays for quantification of multiple variants in wastewater samples (Graber et al., 2021; Lee et al., 2021a, 2021b, 2021c; Yaniv et al., 2021). RT-qPCR methods enable differentiation of specific variant-linked mutations and are more sensitive than sequence-based approaches, allowing for their quantitation, and providing readily interpretable results within hours. However, designing assays for 
medRxiv preprint doi: https://doi.org/10.1101/2021.12.21.21268077; this version posted January $14,2022$. The copyright holder for this preprint (which was not certified by peer review) is the author/funder, who has granted medRxiv a license to display the preprint in It is made available under a CC-BY 4.0 International license.

VOCs is a moving target since emerging VOCs may possess unique mutations that necessitate the development of new assays.

Our group has previously designed RT-qPCR-based methods for the detection of mutations associated with the Alpha variant and the Delta variant in wastewater (Lee et al., 2021a, 2021b, 2021c). The assays are designed based on principles of allele-specific (AS) qPCR (Petruska et al., 1988; Wu et al., 1989). Here, we develop a new set of AS RT-qPCR primers for the detection of the Omicron variant, simultaneously targeting loci Q493R, G496S and Q498R, which are currently specific for Omicron variant. This newly designed assay can be run as a singleplex or as a duplex with an earlier assay designed to target HV69-70del (Lee et al., 2021b, 2021c) for improved convenience.

\section{RESULTS AND DISCUSSION}

In this work we explore and develop allele-specific (AS) RT-qPCR primers that could be used to detect and quantify the Omicron variant in wastewater. We have developed two approaches for Omicron detection, including (1) a new assay that is currently specific for mutations present in the spike gene in Omicron (Figure 1), and (2) targeting the locus 69-70 (HV69-70del) in Omicron, also in the spike gene, that is shared with the Alpha variant (GISAID, 2021a) and developed previously in (Lee et al., 2021b, 2021c). In the new Omicron specific assay, we simultaneously target Omicron mutations Q493R, G496S and Q498R. This stretch of mutations are present in most of the sequences $(97.5 \%)$ classified as Omicron, and can be used to differentiate Omicron from other variants (Table 1). Initial validation with DNA and RNA templates demonstrate good sensitivity and specificity of this assay. In this updated version of the preprint, we have included data from validating both of these assays against full length synthetic Omicron RNA. 
medRxiv preprint doi: https://doi.org/10.1101/2021.12.21.21268077; this version posted January 14,2022 . The copyright holder for this preprint (which was not certified by peer review) is the author/funder, who has granted medRxiv a license to display the preprint in perpetuity.

It is made available under a CC-BY 4.0 International license.

\section{Primer design}

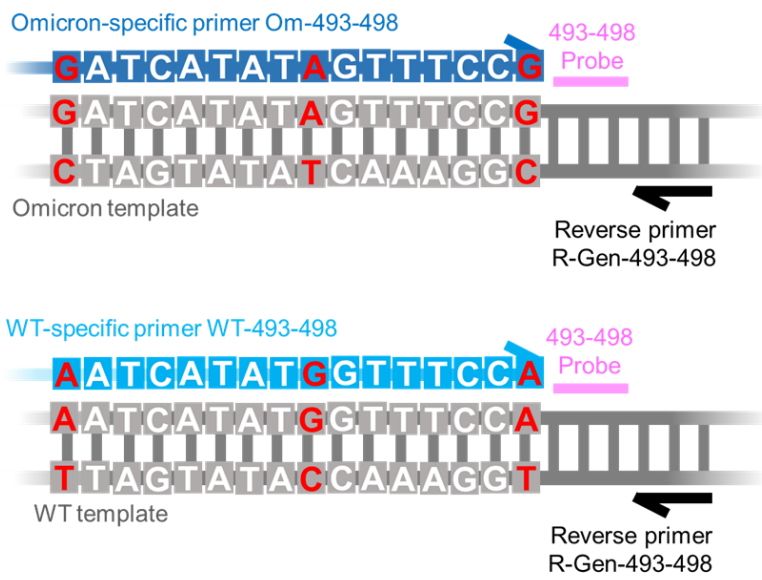

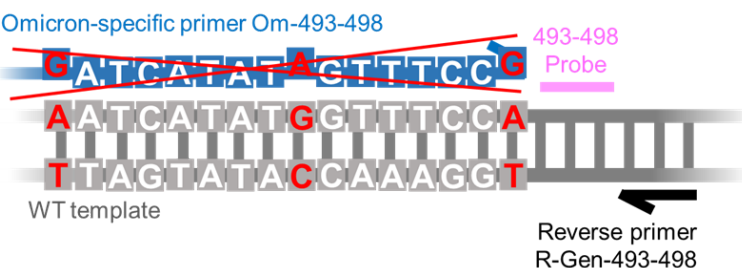

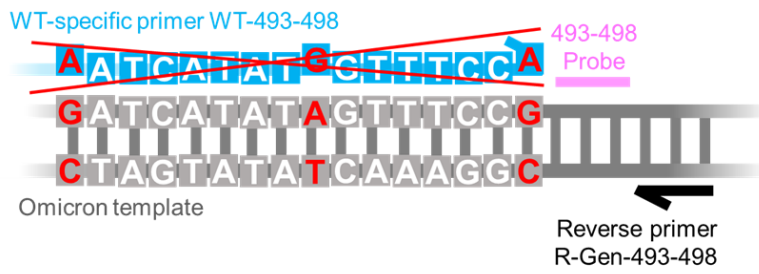

Figure 1. Schematic of the AS RT-qPCR assay targeting Q493R, G496S and Q498R.

Each assay requires a common reverse primer (black) and probe (pink), paired with an Omicron-specific (dark blue) or WT (light blue) primer (dark blue) in the forward direction. Those allele-specific primers are designed to target the mutations of interest (red), with the mutations near the 3 ' end to enhance assay specificity.

\begin{tabular}{|c|c|c|}
\hline $\begin{array}{c}\text { Amino acid positions of } \\
\text { targeted mutations }\end{array}$ & $\begin{array}{c}\text { Frequency in Omicron } \\
\text { variant }\end{array}$ & $\begin{array}{c}\text { Frequency in WT } \\
\text { (non-Omicron) }\end{array}$ \\
\hline $\begin{array}{c}\text { Spike protein Q493R, } \\
\text { G496S, Q498R }\end{array}$ & $97.5 \%$ & $0.001 \%$ \\
\hline
\end{tabular}

Table 1. Frequency of targeted mutations in SARS-CoV-2 Omicron variant. SARS-CoV-2 sequences obtained within the last two months (19th Oct 2021 - 19th Dec 2021) were obtained from the GISAID database. The percentage of Omicron and wild-type (WT) (which includes all non-Omicron) genomes containing each target mutation were used as a gauge to determine reliability of assay at identifying the Omicron variant.

\section{Specificity and cross-reactivity of AS RT-qPCR primers against Omicron and WT RNA}

We validated our assays against both synthetic full length WT and Omicron RNA (Figure 2). The Omicron-specific assay targeting 493-498 and 69-70 do not cross-react with WT RNA below $10^{3}$ and $10^{4}$ copies respectively, conferring sufficient specificity for determining wastewater titers of Omicron, given that the number of copies of SARS-CoV-2 RNA in each reaction containing RNA template from wastewater is typically below $10^{3}$ 
medRxiv preprint doi: https://doi.org/10.1101/2021.12.21.21268077; this version posted January 14,2022 . The copyright holder for this preprint (which was not certified by peer review) is the author/funder, who has granted medRxiv a license to display the preprint in It is made available under a CC-BY 4.0 International license.

(Duvallet et al., 2021; Wu et al., 2022, 2021, 2020). The amplification efficiencies of the Omicron assays for the Omicron RNA and WT assays for WT RNA are above $84.1 \%$ and $85.5 \%$ respectively.

a)

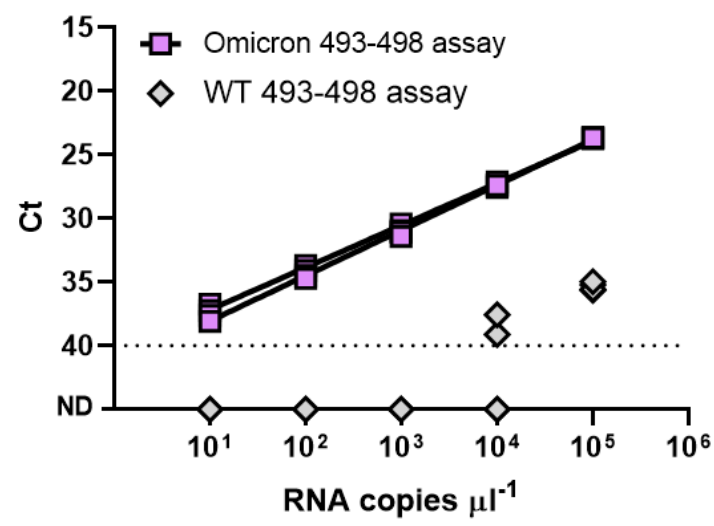

c)

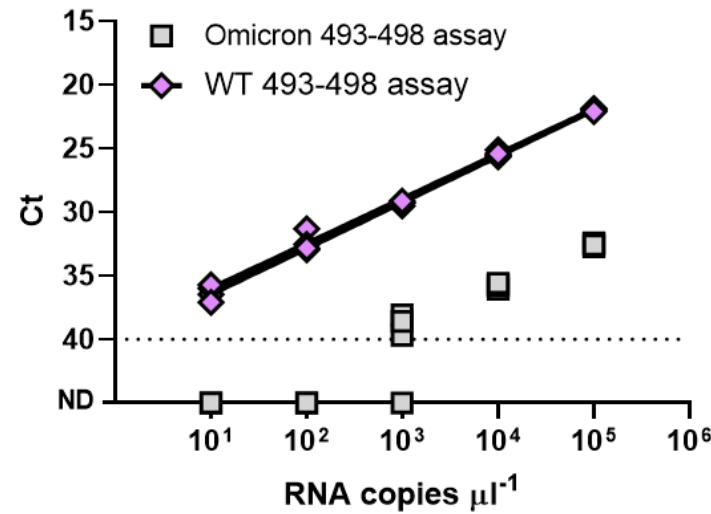

b)

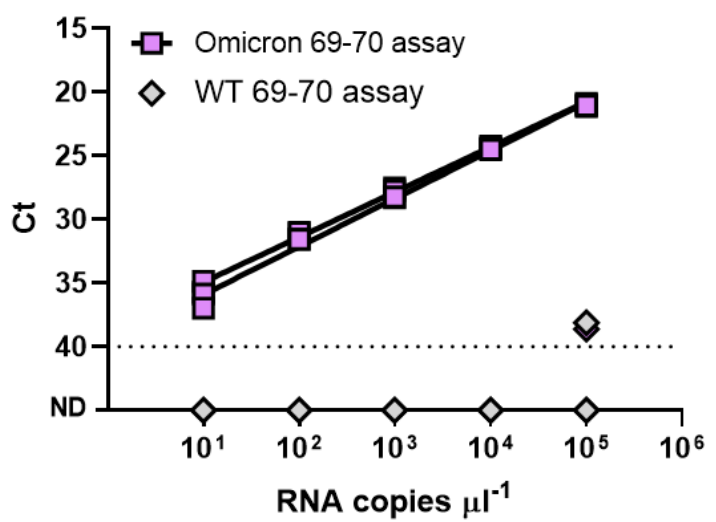

d)

\section{WT RNA}

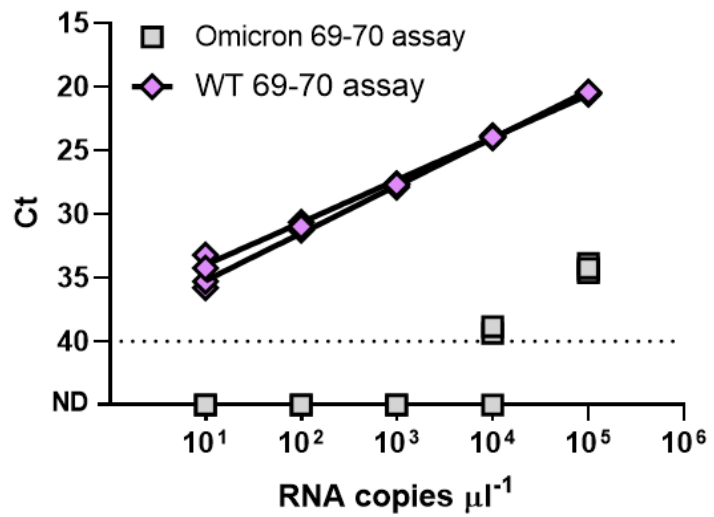

\begin{tabular}{|c|c|c|c|c|}
\hline RNA template & a) Omicron & b) Omicron & c) WT & d) WT \\
\hline Assay & $\begin{array}{c}\text { Omicron } \\
493-498 \text { assay }\end{array}$ & $\begin{array}{c}\text { Omicron } \\
69-70 \text { assay }\end{array}$ & $\begin{array}{c}\text { WT 493-498 } \\
\text { assay }\end{array}$ & $\begin{array}{c}\text { WT 69-70 } \\
\text { assay }\end{array}$ \\
\hline Intercept & $41.6,40.5$ & $39.7,38.5$ & $40.1,39.5$ & $37.3,39.0$ \\
\hline Slope & $-3.56,-3.31$ & $-3.77,-3.54$ & $-3.62,-3.52$ & $-3.34,-3.73$ \\
\hline Efficiency (\%) & $90.9,100$ & $84.1,91.6$ & $89.1,92.3$ & $99.3,85.5$ \\
\hline $\mathbf{R}^{2}$ & $0.998,0.997$ & $0.993,0.996$ & $0.996,0.991$ & $0.995,0.997$ \\
\hline
\end{tabular}


medRxiv preprint doi: https://doi.org/10.1101/2021.12.21.21268077; this version posted January 14, 2022. The copyright holder for this preprint (which was not certified by peer review) is the author/funder, who has granted medRxiv a license to display the preprint in It is made available under a CC-BY 4.0 International license.

Figure 2. Specificity and cross-reactivity of AS RT-qPCR primers against full length WT and Omicron RNA. Purple squares represent tests of Omicron-specific primers to Omicron RNA, and purple diamonds represent tests of WT-specific primers to WT RNA (represented by Delta RNA). Grey diamonds and squares denote tests against RNA of the opposite genotype. The presented data reflect two sets of independent measurements taken on different days.

Using cycle thresholds (Ct) as a proxy for the sensitivity of the assays (Figure 3), we compared Ct values of the AS RT-qPCR assays developed, to those of the U.S. CDC N1 assay across a 10,000-fold difference in target RNA concentrations. WT and Omicron assays targeting 69-70 had comparable sensitivities to the N1 assay while WT and Omicron assays targeting 493-498 had slightly lower sensitivities (2.9 Cts higher on average) compared to the $\mathrm{N} 1$ assay. Nonetheless, all assays were able to robustly detect 10 copies of target RNA.

Omicron RNA

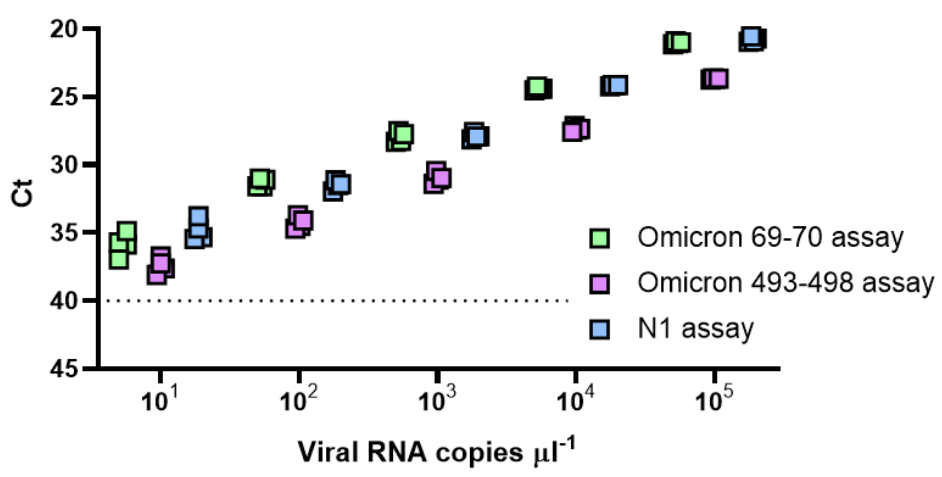

WT RNA

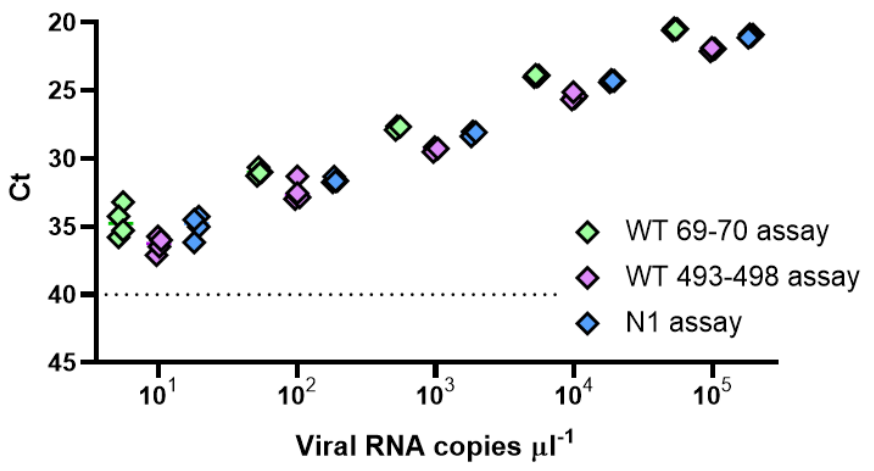


medRxiv preprint doi: https://doi.org/10.1101/2021.12.21.21268077; this version posted January 14,2022 . The copyright holder for this
preprint (which was not certified by peer review) is the author/funder, who has granted medRxiv a license to display the preprint in perpetuity.

It is made available under a CC-BY 4.0 International license .

Figure 3. Ct values for the AS RT-qPCR primers targeting 493-498 and $69-70$ in comparison to the US CDC N1 assay. AS RT-qPCR assays (green and purple) in comparison to the US CDC N1 assay (blue). Squares represent tests against Omicron RNA and diamonds denote tests against WT RNA (represented by Delta RNA). Assays were tested with ten-fold dilutions of their respective full-length synthetic Omicron SARS-CoV-2 RNA or WT SARS-CoV-2 RNA in nuclease-free water. The data shown reflect two sets of independent measurements taken on different days.

\section{DISCUSSION}

The study presented here proposes an AS RT-qPCR assay that has been developed for specific detection and quantitation of the SARS-CoV-2 Omicron variant of concern in wastewater samples. This assay simultaneously targets loci Q493R, G496S and Q498R. Both the WT (non-Omicron) and Omicron assays are highly specific and do not cross-react with RNA of the opposite genotype up to $10^{3}$ and $10^{4}$ copies, respectively. We also mention and validate another assay which has been previously developed and described for the Alpha variant (Lee et al., 2021b,c) for use to indicate presence of the Omicron variant. Both assays (69-70 and 493-498) show good amplification efficiencies and possess sufficient sensitivity and specificity for detection of the Omicron variant in wastewater.

The deletion at locus $69-70$ is found in the Omicron variant and in areas with low prevalence of the Alpha variant, can be used to track dynamics of the Omicron variant, corroborating results from the Omicron-specific assay. While there may be ambiguity if a positive read out with this assay would signify the Alpha or the Omicron variant, as of late Dec 2021 , less than $0.2 \%$ of newly reported sequences is attributed to the Alpha variant (GISAID, 2021b). While not yet demonstrated in this work, assay 69-70 can be combined with the 493-498 assay, into a duplex for greater convenience of handling. Potential duplex combinations are shown in Figure 4. 
medRxiv preprint doi: https://doi.org/10.1101/2021.12.21.21268077; this version posted January $14,2022$. The copyright holder for this preprint (which was not certified by peer review) is the author/funder, who has granted medRxiv a license to display the preprint in perpetuity.

It is made available under a CC-BY 4.0 International license.

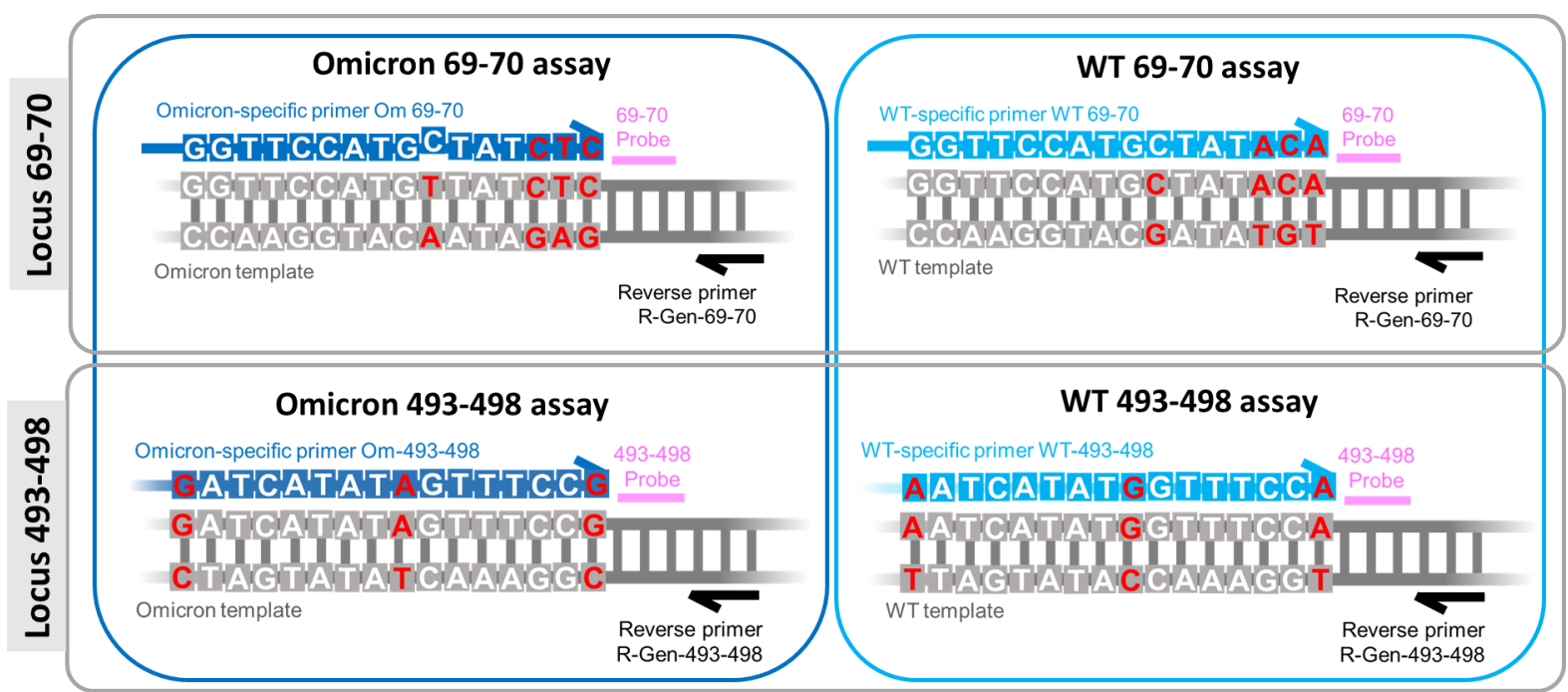

Figure 4. Potential duplex combination for detection of the Omicron variant at two loci

- 69-70 and 493-498 on the spike gene. The assay for the locus 69-70 has been developed in an earlier study on Alpha variant quantification (Lee et al., 2021a, 2021b). The presence of the A67V mutation present as a $\mathrm{C}$ to $\mathrm{T}$ substitution in Omicron which is absent in Alpha, did not affect the performance of the 69-70 assay against Omicron RNA. Omicron variant detection requires performing only the Omicron - specific assays, of which both assays targeting the Omicron variant (Omicron 69-70 assay and Omicron 493-498 assay) can be combined into a reaction as a duplex (dark blue box). Likewise the two WT-specific assays (WT 69-70 assay and WT 493-498 assay) can be combined as another duplex (light blue box).

While variant detection only requires performing the reaction that targets the mutated locus in the SARS-CoV-2 variant of concern, we present assays that target both the WT and the mutant at the same loci. This way, quantification of both WT and mutant loci in wastewater allows us to determine the proportion of WT to the variant sequence at the target loci, if desired. In the first version of the preprint, commercial Omicron variant RNA was not yet available in our laboratory, so the WT assay was used for approximating the performance of the Omicron assay. Here, we update the preprint to include validation of all of these assays against full length synthetic Omicron RNA. While these assays have not yet been validated against Omicron in real wastewater samples, given the rapid increase in circulation of the Omicron VOC, we are sharing these assays and their initial validations for the benefit of the wider wastewater surveillance community. Detailed analytical validation 
medRxiv preprint doi: https://doi.org/10.1101/2021.12.21.21268077; this version posted January 14,2022 . The copyright holder for this
preprint (which was not certified by peer review) is the author/funder, who has granted medRxiv a license to display the preprint in It is made available under a CC-BY 4.0 International license.

against the Omicron variant in wastewater will be performed and reported as an update to this preprint.

\section{MATERIALS AND METHODS}

\section{Determination of frequencies of targeted mutations in Omicron and (WT) non-Omicron} strains. A global masked alignment of SARS-CoV-2 sequences from GISAID aligned to the GISAID reference sequence WIV04 (Zhou et al., 2020) were downloaded on GISAID (19th Dec 2021). We analysed sequences from the recent two months (19th Oct 2021 - 19th Dec 2021). Among $1,082,005$ sequences, $0.81 \%$ sequences were assigned as omicron strains (B.1.1.529 + BA.*) and 99.2\% were assigned as non-omicron strains.

\section{Assay design}

We designed AS RT-qPCR reactions to detect a stretch of mutations in the SARS-CoV-2 spike gene. Primers and probes were designed following our previous work (Lee et al., 2021) and using the Integrated DNA Technologies (IDT)'s PrimerQuest Tool. Target mutations were placed near the 3' end of the forward primer. All primers were designed to have a melting temperature in the range of $59-65^{\circ} \mathrm{C}$ and the probes in the range of $64-72^{\circ} \mathrm{C}$. Probes were designed to anneal to the same strand as the allele-specific primer, with the probe as close to the $3^{\prime}$-end of the Allele Specific (AS) primers as possible. Guanines are avoided at the $5^{\prime}$-end of the probe. WT primers are designed to bind to all non-Omicron sequences. The probe for $493-498$ is designed with mixed bases at two positions to enable binding to both WT (non-Omicron) and Omicron sequences. All primers and probes were purchased from IDT (Table 2).

Table 2. AS RT-qPCR primer sequences. Allele-specific nucleotides are marked bold. Gen denotes general (common primers), and are used in both WT and omicron-specific reactions. Om denotes Omicron, and is used in Omicron-specific reactions. WT denotes wild type, and is used for WT (non-Omicron)-specific reactions. If the assays were to be duplexed, one of the probes should be synthesised with a different fluorophore i.e. HEX. Nucleotide underlined may be changed to a $T$ to account for the A67V that is present in Omicron but not in Alpha. Retaining it as a $\mathrm{C}$ does not affect assay performance. 
medRxiv preprint doi: https://doi.org/10.1101/2021.12.21.21268077; this version posted January $14,2022$. The copyright holder for this preprint (which was not certified by peer review) is the author/funder, who has granted medRxiv a license to display the preprint in perpetuity.

It is made available under a CC-BY 4.0 International license .

\begin{tabular}{|c|c|c|c|c|}
\hline $\begin{array}{l}\text { Location } \\
\text { and amino } \\
\text { acid } \\
\text { position(s) }\end{array}$ & Primer name & Oligonucleotide Sequence $\left(5^{\prime}>3^{\prime}\right)$ & \begin{tabular}{|l} 
Amplico \\
n size \\
(bp)
\end{tabular} & Reference \\
\hline $\begin{array}{l}\text { Spike } \\
\text { protein } \\
\text { HV69-70 } \\
\text { deletion }\end{array}$ & $\begin{array}{l}\text { F-WT-69-70 } \\
\text { F-Om-69-70 } \\
\text { Ps-Gen-69-70 } \\
\text { R-Gen-69-70 }\end{array}$ & $\begin{array}{l}\text { ATGTTACTTGGTTCCATGㅡㅡATACA } \\
\text { ATGTTACTTGGTTCCATGㅡATCTC } \\
\text { /56-FAM/TCTCTGGGACCAATGGTACTAAGAG } \\
\text { GT/3BHQ_1/ } \\
\text { AAATGGTAGGACAGGGTTATCAA }\end{array}$ & 77 & $\begin{array}{l}\text { Lee et } \\
\text { al., } \\
2021 a, b\end{array}$ \\
\hline $\begin{array}{l}\text { Spike } \\
\text { protein } \\
493-498\end{array}$ & $\begin{array}{l}\text { F-WT-493-498 } \\
\text { F-Om-493-498 } \\
\text { Ps-Gen-493-498 } \\
\text { R-Gen-493-498 }\end{array}$ & $\begin{array}{l}\text { CTTTCCTTTACAATCATATGGTTTCCA } \\
\text { CTTCCTTACGATCATATAGTTCCG } \\
\text { /56-FAM/ACCCACTWATGGTGTTGGTYACCA/3 } \\
\text { BHQ_1/ } \\
\text { AGTTGCTGGTGCATGTAGAA }\end{array}$ & 103 & $\begin{array}{l}\text { This } \\
\text { paper }\end{array}$ \\
\hline
\end{tabular}

\section{Analysis of assays against DNA standards by qPCR}

qPCR reactions were performed using TaqMan Fast Advanced Master Mix (ThermoFisher \#4444556) at a final volume of $10 \mu \mathrm{L}$ in duplicates, according to the manufacturer's recommendations with a final primer concentration of $0.5 \mu \mathrm{M}$ and probe of $0.2 \mu \mathrm{M}$ with $1 \mu \mathrm{L}$ of DNA template, at $20 \mathrm{~s}$ at $95{ }^{\circ} \mathrm{C}, 40$ cycles of $3 \mathrm{~s}$ at $95{ }^{\circ} \mathrm{C}$ and $30 \mathrm{~s}$ at $60{ }^{\circ} \mathrm{C}$. A single reverse primer and probe was used with each allele-specific forward primer (Table 3).

Table 3. Primers and probes in each assay

\begin{tabular}{|l|l|l|l|l|}
\hline Locus & Assay & Forward primer & Reverse primer & Probe \\
\hline \multirow{3}{*}{$493-498$} & WT 493-498 & F-WT-493-498 & \multirow{2}{*}{ R-Gen-493-498 } & Ps-Gen-493-498 \\
\cline { 2 - 4 } & Omicron 493-498 & F-Om-493-498 & & \\
\hline \multirow{2}{*}{$69-70$} & WT 69-70 & F-WT-69-70 & \multirow{2}{*}{ R-Gen-69-70 } & Ps-Gen-69-70 \\
\cline { 2 - 4 } & Omicron 69-70 & F-Om-69-70 & & \\
\hline
\end{tabular}

\section{RNA Standards and their quantification by RT-ddPCR}

Twist synthetic SARS-CoV-2 RNA control 23 (Delta, B.1.617.2) was used as the WT RNA standard, as it contains the wild-type (WT) sequence at the three targeted mutant loci. Twist synthetic SARS-CoV-2 RNA control 48 (B.1.1.529/BA.1) was used as the RNA standard for Omicron. RNA standards were prepared as single-use aliquots. Controls 23 and 48 were 
medRxiv preprint doi: https://doi.org/10.1101/2021.12.21.21268077; this version posted January 14,2022 . The copyright holder for this
preprint (which was not certified by peer review) is the author/funder, who has granted medRxiv a license to display the preprint in perpetuity.

It is made available under a CC-BY 4.0 International license .

quantified by digital droplet RT-PCR (dd RT-PCR) to be $3.96 \times 10^{5}$ copies/ $\mu \mathrm{L}$ and $4.55 \times 10^{5}$ copies/ $\mu \mathrm{L}$ respectively. Quantification was performed using One-Step RT-ddPCR Advanced Kit for Probes \#1864022 (Bio-Rad) following manufacturer's recommendations.

\section{Analysis of assays against RNA standards by RT-qPCR}

AS RT-qPCR was performed using the Taqman Virus 1-Step master mix (Thermofisher \#4444434) with technical duplicates, at a final volume of $10 \mu \mathrm{L}$, according to the manufacturer's recommendations. A single reverse primer and probe was used with each allele-specific forward primer (Table 3). The final concentration of the AS RT-qPCR primers were $500 \mathrm{nM}$, probe at $200 \mathrm{nM}$, with $1 \mu \mathrm{L}$ of template. No template controls were included for each assay and none of them amplified. The reactions are setup using electronic pipettes (Eppendorf) and performed on a Bio-Rad CFX384 real-time PCR instrument under the following conditions, $5 \mathrm{~min}$ at $50^{\circ} \mathrm{C}$ and $20 \mathrm{~s}$ at $95^{\circ} \mathrm{C}$, followed by 45 cycles of $3 \mathrm{~s}$ at $95^{\circ} \mathrm{C}$ and $30 \mathrm{~s}$ at $60^{\circ} \mathrm{C}$.

\section{Data analysis}

Frequency of targeted mutations was analysed using Python. QPCR data was analysed using Microsoft Excel and Graphpad Prism. Graphs were presented using Graphpad Prism.

\section{Data availability}

Source data will be made available upon request.

\section{Declaration of competing interests}

EJA is an advisor to Biobot Analytics and holds shares in the company.

\section{Funding Statement}

This research is supported by the National Research Foundation, Prime Minister's Office, Singapore, under its Campus for Research Excellence and Technological Enterprise (CREATE) program funding to the Singapore-MIT Alliance for Research and Technology (SMART) Antimicrobial Resistance Interdisciplinary Research Group (AMR IRG) and the Intra-CREATE Thematic Grant (Cities) grant NRF2019-THE001-0003a to JT and EJA and funding from the Singapore Ministry of Education and National Research Foundation 
medRxiv preprint doi: https://doi.org/10.1101/2021.12.21.21268077; this version posted January 14,2022 . The copyright holder for this preprint (which was not certified by peer review) is the author/funder, who has granted medRxiv a license to display the preprint in It is made available under a CC-BY 4.0 International license.

through an RCE award to Singapore Centre for Environmental Life Sciences Engineering (SCELSE).

\section{Contributions}

EJA and JT conceptualized the project. WLL designed the experiments. WLL, XG, FA, FC, HC, HC, FW, AX, ML, FJDC and GWCK analyzed the data. WLL, JYRT and CYJL performed experiments. All authors contributed to writing the manuscript. WLL, JT and EJA supervised the project. All authors read and approved the manuscript.

\section{Acknowledgements}

We thank members of the Biobot Analytics, Inc team for helpful discussions.

\section{REFERENCES}

CDC, 2021. SARS-CoV-2 Variant Classifications and Definitions [WWW Document]. URL https://www.cdc.gov/coronavirus/2019-ncov/variants/variant-info.html (accessed 7.9.21).

Crits-Christoph, A., Kantor, R.S., Olm, M.R., Whitney, O.N., Al-Shayeb, B., Lou, Y.C., Flamholz, A., Kennedy, L.C., Greenwald, H., Hinkle, A., Hetzel, J., Spitzer, S., Koble, J., Tan, A., Hyde, F., Schroth, G., Kuersten, S., Banfield, J.F., Nelson, K.L., 2021. Genome Sequencing of Sewage Detects Regionally Prevalent SARS-CoV-2 Variants. MBio 12, e02703-20. https://doi.org/10.1128/mBio.02703-20

Duvallet, C., Wu, F., McElroy, K.A., Imakaev, M., Endo, N., Xiao, A., Zhang, J., Floyd-O'Sullivan, R., Powell, M.M., Mendola, S., Wilson, S.T., Cruz, F., Melman, T., Sathyanarayana, C.L., Olesen, S.W., Erickson, T.B., Ghaeli, N., Chai, P., Alm, E., Matus, M., 2021. Nationwide trends in COVID-19 cases and SARS-CoV-2 wastewater concentrations in the United States. medRxiv 2021.09.08.21263283. https://doi.org/10.1101/2021.09.08.21263283

Fontenele, R.S., Kraberger, S., Hadfield, J., Driver, E.M., Bowes, D., Holland, L.A., Faleye, T.O.C., Adhikari, S., Kumar, R., Inchausti, R., Holmes, W.K., Deitrick, S., Brown, P., Duty, D., Smith, T., Bhatnagar, A., Yeager, R.A., Holm, R.H., von Reitzenstein, N.H., Wheeler, E., Dixon, K., Constantine, T., Wilson, M.A., Lim, E.S., Jiang, X., Halden, R.U., Scotch, M., Varsani, A., 2021. High-throughput sequencing of SARS-CoV-2 in wastewater provides insights into circulating variants. medRxiv 2021.01.22.21250320. https://doi.org/10.1101/2021.01.22.21250320 
medRxiv preprint doi: https://doi.org/10.1101/2021.12.21.21268077; this version posted January 14,2022 . The copyright holder for this preprint (which was not certified by peer review) is the author/funder, who has granted medRxiv a license to display the preprint in perpetuity.

It is made available under a CC-BY 4.0 International license .

Graber, T.E., Mercier, É., Bhatnagar, K., Fuzzen, M., D’Aoust, P.M., Hoang, H.-D., Tian, X., Towhid, S.T., Plaza-Diaz, J., Eid, W., Alain, T., Butler, A., Goodridge, L., Servos, M., Delatolla, R., 2021. Near real-time determination of B.1.1.7 in proportion to total SARS-CoV-2 viral load in wastewater using an allele-specific primer extension PCR strategy. Water Res. 205, 117681. https://doi.org/https://doi.org/10.1016/j.watres.2021.117681

GISAID, 2021a. Shared mutations [WWW Document]. URL https://covariants.org/shared-mutations (accessed 12.19.21).

GISAID, 2021b. Tracking of variants [WWW Document]. URL https://www.gisaid.org/hcov19-variants/ (accessed 21.19.21).

Gwinn, M., MacCannell, D., Armstrong, G.L., 2019. Next-Generation Sequencing of Infectious Pathogens. JAMA 321, 893-894. https://doi.org/10.1001/jama.2018.21669

Harvey, W.T., Carabelli, A.M., Jackson, B., Gupta, R.K., Thomson, E.C., Harrison, E.M., Ludden, C., Reeve, R., Rambaut, A., Peacock, S.J., Robertson, D.L., Consortium, C.-19 G.U.K. (COG-U., 2021. SARS-CoV-2 variants, spike mutations and immune escape. Nat. Rev. Microbiol. 19, 409-424. https://doi.org/10.1038/s41579-021-00573-0

Lee, W.L., Gu, X., Armas, F., Chandra, F., Chen, H., Wu, F., Leifels, M., Xiao, A., Desmond Chua, F.J., Kwok, G.W.C., Jolly, S., Lim, C.Y.J., Thompson, J., Alm, E.J., 2021a. Quantitative SARS-CoV-2 tracking of variants Delta, Delta plus, Kappa and Beta in wastewater by allele-specific RT-qPCR. medRxiv 2021.08.03.21261298. https://doi.org/10.1101/2021.08.03.21261298

Lee, W.L., Imakaev, M., Armas, F., McElroy, K.A., Gu, X., Duvallet, C., Chandra, F., Chen, H., Leifels, M., Mendola, S., Floyd-O'Sullivan, R., Powell, M.M., Wilson, S.T., Berge, K.L.J., Lim, C.Y.J., Wu, F., Xiao, A., Moniz, K., Ghaeli, N., Matus, M., Thompson, J., Alm, E.J., 2021b. Quantitative SARS-CoV-2 Alpha Variant B.1.1.7 Tracking in Wastewater by Allele-Specific RT-qPCR. Environ. Sci. Technol. Lett. https://doi.org/10.1021/acs.estlett.1c00375

Lee, W.L., McElroy, K.A., Armas, F., Imakaev, M., Gu, X., Duvallet, C., Chandra, F., Chen, H., Leifels, M., Mendola, S., Floyd-O'Sullivan, R., Powell, M.M., Wilson, S.T., Wu, F., Xiao, A., Moniz, K., Ghaeli, N., Matus, M., Thompson, J., Alm, E.J., 2021c. Quantitative detection of SARS-CoV-2 B.1.1.7 variant in wastewater by allele-specific RT-qPCR. medRxiv 2021.03.28.21254404. https://doi.org/10.1101/2021.03.28.21254404

Medema, G., Heijnen, L., Elsinga, G., Italiaander, R., Brouwer, A., 2020. Presence of SARS-Coronavirus-2 RNA in Sewage and Correlation with Reported COVID-19 
medRxiv preprint doi: https://doi.org/10.1101/2021.12.21.21268077; this version posted January $14,2022$. The copyright holder for this preprint (which was not certified by peer review) is the author/funder, who has granted medRxiv a license to display the preprint in perpetuity.

It is made available under a CC-BY 4.0 International license .

Prevalence in the Early Stage of the Epidemic in The Netherlands. Environ. Sci. Technol. Lett. https://doi.org/10.1021/acs.estlett.0c00357

Napit, R., Manandhar, P., Chaudhary, A., Shrestha, B., Poudel, A., Raut, R., Pradhan, S., Raut, S., Mathema, S., Rajbhandari, R., Dixit, S., Schwind, J.S., Johnson, C.K., Mazet, J.K., Karmacharya, D., 2021. Rapid genomic surveillance of SARS-CoV-2 in a dense urban community using environmental (sewage) samples. medRxiv 2021.03.29.21254053. https://doi.org/10.1101/2021.03.29.21254053

Pal, M., Berhanu, G., Desalegn, C., Kandi, V., 2020. Severe Acute Respiratory Syndrome Coronavirus-2 (SARS-CoV-2): An Update. Cureus 12, e7423-e7423. https://doi.org/10.7759/cureus.7423

Petruska, J., Goodman, M.F., Boosalis, M.S., Sowers, L.C., Cheong, C., Tinoco, I.J., 1988. Comparison between DNA melting thermodynamics and DNA polymerase fidelity. Proc. Natl. Acad. Sci. U. S. A. 85, 6252-6256. https://doi.org/10.1073/pnas.85.17.6252

Polo, D., Quintela-Baluja, M., Corbishley, A., Jones, D.L., Singer, A.C., Graham, D.W., Romalde, J.L., 2020. Making waves: Wastewater-based epidemiology for COVID-19 - approaches and challenges for surveillance and prediction. Water Res. 186, 116404. https://doi.org/https://doi.org/10.1016/j.watres.2020.116404

Pulliam, J.R.C., van Schalkwyk, C., Govender, N., von Gottberg, A., Cohen, C., Groome, M.J., Dushoff, J., Mlisana, K., Moultrie, H., 2021. Increased risk of SARS-CoV-2 reinfection associated with emergence of the Omicron variant in South Africa. medRxiv 2021.11.11.21266068. https://doi.org/10.1101/2021.11.11.21266068

Randazzo, W., Truchado, P., Cuevas-Ferrando, E., Simón, P., Allende, A., Sánchez, G., 2020. SARS-CoV-2 RNA in wastewater anticipated COVID-19 occurrence in a low $\begin{array}{llll}\text { prevalence } \quad \text { area. Water } & \text { Res. } & 181, & 15942 .\end{array}$ https://doi.org/10.1016/j.watres.2020.115942

Thompson, J.R., Nancharaiah, Y. V, Gu, X., Lee, W.L., Rajal, V.B., Haines, M.B., Girones, R., Ng, L.C., Alm, E.J., Wuertz, S., 2020. Making waves: Wastewater surveillance of SARS-CoV-2 for population-based health management. Water Res. 184, 116181. https://doi.org/10.1016/j.watres.2020.116181

Van Poelvoorde, L.A.E., Delcourt, T., Coucke, W., Herman, P., De Keersmaecker, S.C.J., Saelens, X., Roosens, N., Vanneste, K., 2021. Strategy and performance evaluation of low-frequency variant calling for SARS-CoV-2 in wastewater using targeted deep Illumina sequencing. medRxiv 2021.07.02.21259923. https://doi.org/10.1101/2021.07.02.21259923 
medRxiv preprint doi: https://doi.org/10.1101/2021.12.21.21268077; this version posted January $14,2022$. The copyright holder for this preprint (which was not certified by peer review) is the author/funder, who has granted medRxiv a license to display the preprint in perpetuity.

It is made available under a CC-BY 4.0 International license .

Wang, H., Miller, J.A., Verghese, M., Sibai, M., Solis, D., Mfuh, K.O., Jiang, B., Iwai, N., Mar, M., Huang, C., Yamamoto, F., Sahoo, M.K., Zehnder, J., Pinsky, B.A., 2021. Multiplex SARS-CoV-2 Genotyping PCR for Population-Level Variant Screening and Epidemiologic Surveillance. J. Clin. Microbiol. 59. https://doi.org/10.1101/2021.04.20.21255480

WHO, 2020. WHO Director-General's opening remarks at the media briefing on COVID-19 - 11 March 2020 [WWW Document]. URL https://www.who.int/director-general/speeches/detail/who-director-general-s-ope ning-remarks-at-the-media-briefing-on-covid-19---11-march-2020 (accessed 12.19.21).

WHO, 2021a. Tracking SARS-CoV-2 variants [WWW Document]. URL https://www.who.int/en/activities/tracking-SARS-CoV-2-variants/ (accessed 12.19.21).

WHO, 2021b. Enhancing Readiness for Omicron (B.1.1.529): Technical Brief and Priority Actions for Member States [WWW Document]. URL https://www.who.int/publications/m/item/enhancing-readiness-for-omicron-(b.1.1. 529)-technical-brief-and-priority-actions-for-member-states (accessed 12.19.21).

Wu, D.Y., Ugozzoli, L., Pal, B.K., Wallace, R.B., 1989. Allele-specific enzymatic amplification of beta-globin genomic DNA for diagnosis of sickle cell anemia. Proc. Natl. Acad. Sci. U. S. A. 86, 2757-2760. https://doi.org/10.1073/pnas.86.8.2757

Yaniv, K., Ozer, E., Shagan, M., Lakkakula, S., Plotkin, N., Bhandarkar, N.S., Kushmaro, A., 2021. Direct RT-qPCR assay for SARS-CoV-2 variants of concern (Alpha, B.1.1.7 and Beta, B.1.351) detection and quantification in wastewater. Environ. Res. 201, 111653. https://doi.org/10.1016/j.envres.2021.111653

Wu, F., Xiao, A., Zhang, J., Moniz, K., Endo, N., Armas, F., Bonneau, R., Brown, M.A., Bushman, M., Chai, P.R., Duvallet, C., Erickson, T.B., Foppe, K., Ghaeli, N., Gu, X., Hanage, W.P., Huang, K.H., Lee, W.L., Matus, M., McElroy, K.A., Nagler, J., Rhode, S.F., Santillana, M., Tucker, J.A., Wuertz, S., Zhao, S., Thompson, J., Alm, E.J., 2022. SARS-CoV-2 RNA concentrations in wastewater foreshadow dynamics and clinical presentation of new COVID-19 cases. Sci. Total Environ. 805, 150121. https://doi.org/https://doi.org/10.1016/j.scitotenv.2021.150121

Wu, F., Xiao, A., Zhang, J., Moniz, K., Endo, N., Armas, F., Bushman, M., Chai, P.R., Duvallet, C., Erickson, T.B., Foppe, K., Ghaeli, N., Gu, X., Hanage, W.P., Huang, K.H., Lee, W.L., Matus, M., McElroy, K.A., Rhode, S.F., Wuertz, S., Thompson, J., Alm, E.J., 2021. Wastewater Surveillance of SARS-CoV-2 across 40 U.S. states. medRxiv 2021.03.10.21253235. https://doi.org/10.1101/2021.03.10.21253235 
medRxiv preprint doi: https://doi.org/10.1101/2021.12.21.21268077; this version posted January 14, 2022. The copyright holder for this preprint (which was not certified by peer review) is the author/funder, who has granted medRxiv a license to display the preprint in It is made available under a CC-BY 4.0 International license .

Wu, F., Zhang, J., Xiao, A., Gu, X., Lee, W.L., Armas, F., Kauffman, K., Hanage, W., Matus, M., Ghaeli, N., Endo, N., Duvallet, C., Poyet, M., Moniz, K., Washburne, A.D., Erickson, T.B., Chai, P.R., Thompson, J., Alm, E.J., 2020. SARS-CoV-2 Titers in Wastewater Are Higher than Expected from Clinically Confirmed Cases. mSystems 5, e00614-20. https://doi.org/10.1128/mSystems.00614-20

Zhou, P., Yang, X.-L., Wang, X.-G., Hu, B., Zhang, L., Zhang, W., Si, H.-R., Zhu, Y., Li, B., Huang, C.-L., Chen, H.-D., Chen, J., Luo, Y., Guo, H., Jiang, R.-D., Liu, M.-Q., Chen, Y., Shen, X.-R., Wang, X., Zheng, X.-S., Zhao, K., Chen, Q.-J., Deng, F., Liu, L.-L., Yan, B., Zhan, F.-X., Wang, Y.-Y., Xiao, G.-F., Shi, Z.-L., 2020. A pneumonia outbreak associated with a new coronavirus of probable bat origin. Nature 579, 270-273. https://doi.org/10.1038/s41586-020-2012-7 